Science Life

\title{
DEVELOPMENT OF POTATO VARIETIES IN LATVIA
}

\author{
Ilze Skrabule and Gunta Bebre
}

State Priekuḷi Plant Breeding Institute, Zinātnes iela 1a, Priekuḷi LV-4126, LATVIA;

ilze.skrabule@priekuliselekcija.Iv

\begin{abstract}
The first potato varieties that reached the territory of Latvia were empirically selected clones from genetically diverse material brought from South America to Europe. In the $19^{\text {th }}$ century, when agricultural production rapidly developed, the demand for high yielding potato varieties suitable to local growing conditions increased. Therefore, potato variety evaluation trials were set up. Scientifically-based potato breeding in Latvia was launched by $P$. Knappe. The potato breeding programme in Priekuli Plant Breeding Station was started in 1931, and has still continued. Several breeding methods were used by potato breeders E. Knape, V. Gaujers, G. Bebre and others in Priekuli. Potato breeding for short periods was carried out in several other places in Latvia: Stende, Carnikava, and Lejaskurzeme. The method of elimination of diseases in potato seed material and high quality seed material production was implemented in Priekuli. More than 60 potato varieties have been created in Latvia, some of them were and still are in demand in agricultural production.
\end{abstract}

\section{FIRST POTATO VARIETIES}

The potatoes (Solanum tuberosum) that reached Europe in the $16^{\text {th }}$ century were themselves hybrids, descendents of diverse South American varieties and species. The propagation by true seed provided the diversity of germinated plants. When propagation with tubers was introduced, the selection of the best plants or tubers became possible. Careful selection could provide uniform material with high yield potential, large tubers and similar tuber appearance. The selected material yielded three or four times more than the hybrid population (Salaman, 1949). The first potato varieties widely spread in Europe and North America were created in an empirical way (Salaman, 1949; Bradshaw and Mackay, 1994). Probably, this kind of potato variety was first brought to the territory of Latvia in the $17^{\text {th }}$ century (Gaujers, 1969). The introduction of potato crops in agricultural production was very difficult in the territory of Latvia. Only in the $19^{\text {th }}$ century did cultivation of potato become a part of farmer crop production. The desire to grow the most suitable varieties for local growing conditions appeared, so farmers became interested in evaluation of available potato varieties. Special trials for evaluation of different varieties brought from European countries were set up in several manors. A large assessment trial of potato varieties was conducted in Priekul,i manor fields in 1838. A total of 119 potato varieties originating from Germany, England, France, the Netherlands, Switzerland, Denmark, Algeria as well as North and South America continents were included in the trial conducted by J. Krēsliņš (Gaujers, 1983; Strods, 1992). The report of this investigation was published in the Vidzeme Agricultural Yearbook 1839, which was printed in Dorpat (today Tartu, Estonia). Later, several publications in popular magazines contained descriptions of potato varieties. An introduction to varieties of different maturity and suitability to ways of utili- zation was published in the magazine 'Mājas Viesis' by J. Vāgners in 1894, which included the early table varieties 'Early Rose', 'Alpha', and 'Bisquit'; late table varieties 'Magnum Bonum', 'Royal Norfolk', and 'Ruso'; varieties for feeding 'Aurora', 'Champion' and Blaue Riesen'; and varieties for alcohol production 'Reichskanzler' and 'Juno' (Gaujers, 1983). During that time the same variety grown in different regions usually had several names, and the practise of giving local names to the same variety was in fashion (Salaman, 1949). The popular potato variety from the Netherlands, 'Zeeuwsche Blauwe', in Vidzeme was called 'Mazie Zilie' or 'Grāpī̌si', but in Estonia - 'Lilla Pujat'. Several so- called local potato varieties were grown in farmers' fields at the beginning of the 20th century: 'Rīgas Vietējie', 'Sarkanie Vecauces', 'Celmina sarkanie' and others. However, it is still unclear whether those varieties were local breeds or foreign varieties that had lost their original name (Gaujers, 1983).

The spread of diseases that reduced tuber yield forced development of new varieties resistant to pests. Three most destructive pests for potato in the $19^{\text {th }}$ century were the plant degeneration or virus diseases: late blight (Phythophthora infestans (Mont.) de Bary) and wart disease (Synhytrium endobioticum (Schilb.) (Salaman, 1949). For a long time, potato variety breeding in Europe and North America was conducted by fanciers in an empirical way. Only at the end of the $19^{\text {th }}$ century were scientists involved in developing potato varieties with specific traits (Salaman, 1949; Bradshaw and Mackay, 1994).

\section{CONTRIBUTION OF P. KNAPPE}

Pēteris Knappe (1872-1960) was the first person in Latvia who devoted his research to potato breeding. He had received excellent education and worked as a teacher. He went to Paris 


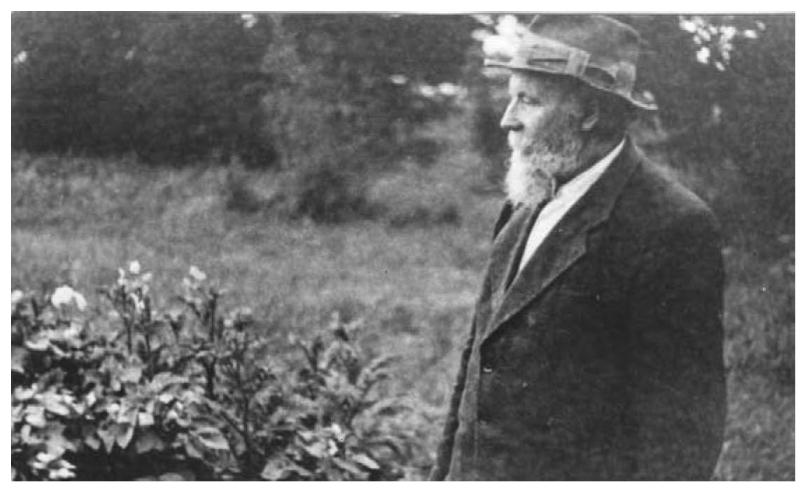

Potato breeder Pēteris Knappe, 1950s

as a teacher in 1903. Parallel to teaching, P. Knappe started his studies of natural science at Sorbonne University. He acquired practical breeding skills in several plant breeding enterprises operating at that time in Europe. When P. Knappe returned to Latvia, he decided to develop a similar plant breeding farm to the one existing in Western Europe. He asked scientists from Europe and America to contribute samples of different potato species, and he made collection. The potato samples received from distinguished researchers as Bukasov S. (Leningrad, today St. Petersburg, Russia), Steward W. (Washington, USA), Schik R. (Muncheberg, Germany) as well as from maintainers of potato species collections in Argentina, Chile, Ecuador, Columbia and Uruguay were evaluated and described in field trials. In correspondence with scientists of the N. I. Vavilov Plant Production Institute (Leningrad, Soviet Union, Russia), P. Knappe exchanged species descriptions and classification of wild species. Rewarding P. Knappes contribution in the description and detection of wild potato species, one of the wild potato forms 'Papa del Cerro' was called Solanum chacoense f. knappei Juz.et Buk. (Gaujers, 1983; Букасов, 1973).

P. Knappe focused his work on introduction of resistance to late blight and other diseases in potato varieties, using hybridisation between cultivated and wild species (Table 1). He used S. demissium, S. maglia, S. commesonii, S. kesselbrenneri, S. ajuscoense and other species in crosses and obtained several significant hybrids for future implementation in breeding.

The most significant potato variety developed by P. Knappe was 'Vāle', medium late maturity, containing gene R1 which

Table 1

PEDIGREE OF SOME SIGNIFICANT POTATO VARIETIES DEVELOPED BY P. KNAPPE, 1913-1950

\begin{tabular}{l|ll}
\hline \multicolumn{1}{c|}{ Type of hybridization } & Variety & \multicolumn{1}{c}{ Pedigree } \\
\hline $\begin{array}{l}\text { Hybridization between } \\
\text { commercial varieties }\end{array}$ & Vāle & $\begin{array}{l}\text { Zwickauer Fruhe // Wildling VI / } \\
\text { Deodara }\end{array}$ \\
& Rota & Fortuna / Chance // Konsum \\
& Baiba & Fortuna / Schlesische Klossel \\
& Spodra & Reichskanzler / Starkereiche I \\
Interspecific hybridization & Ausma & $\begin{array}{l}\text { S. andigenum f. papa runa / Golden } \\
\text { Marvel }\end{array}$ \\
& Herters & $\begin{array}{l}\text { S. commersioniif. Montevideo / S. } \\
\text { tuberosum diversa } \\
\end{array}$ \\
& Barbara & Caliban (S. demmisium/...)// \\
& Majestic / Idylle
\end{tabular}

provides resistance to $P$. infestans race 1 . Unfortunately, the variety was not resistant to potato wart disease Synchytrium endobioticum (Roze, 1953; Roze and Knape, 1954; Букасов, 1973; Gaujers, 1983).

\section{BEGINNING OF POTATO BREEDING IN PRIEKUḶI}

Evaluation trials of potato varieties as well as potato management trials have been carried out at Priekuḷi Plant Breeding and Experimental Station since its establishment in 1913. The special department of potato breeding was organised in 1931. Erihs Knappe, previously an agronomist, a known expert in potato crop, was invited to lead the department. E. Knappe had been dealing with potato breeding as an enthusiast since 1922 . He brought previously developed potato breeding material, about 1600 samples, to Priekuli. E. Knappe used a method of hybridisation between varieties and selection of outstanding clones in his breeding work. The tasks of the new department were to develop new varieties suitable to local growing conditions, and propagation and providing seed material of new varieties as well as old varieties with reduced "degenerated" or virus diseased plants and tubers in seed material. E. Knappe devoted a lot of effort to development of potato seed material export. The first stock of qualitative potato seed material from Latvia was exported in 1934. Potatoes were mainly sent to France (varieties 'Bintje', Erstling', and 'Juli'), but seed material was demanded in Spain, Portugal, Lithuania and Italy as well.

Several varieties bred in Priekuḷi were offered to Latvia farmers in 1930s: 'Agrie Smilšu', 'Lieldienolas', 'Zemgales Milži', 'Eksports', and 'Erna' (later renamed 'Priekul,u Visagrie').

E. Knappe repatriated to Germany in 1939 before the Second World War. Some of the potato varieties developed by him were later widely produced not only in Latvia, but in several regions of the Soviet Union (SU). For example, 'Priekulu Visagrie' was one of the most well-known varieties in the SU during the 1950s (Table 2) (Holms, 1992).

The breeding work in Priekul,i was continued by E. Knappe confreres Rūdolfs Roze and Emīls Pētersons. During the Second World War, hybridisation and selection were continued, and several new varieties were selected and implemented from breeding material: 'Balva', 'Vidzemes Vēlie', and 'Izstādes'. In 1944, at the end of the war, only E. Pêtersons stayed at the Station and tried to save valuable potato seed material.

\section{CHANGES AND BREEDING METHODS DURING SO- VIET TIME}

After the Second World War, in 1945, Latvia again became a United Socialist Republic in the Soviet Union. Scientific information mostly came from the SU. At that time, genetics as science and application of hybridisation in plant breeding were strongly denied in the SU. As a special method, the so-called vegetative hybridisation was introduced.

E. Pētersons, who was at that time a potato breeder in Priekuli Breeding and Experimental Station, using vegetative hybridisation created more than 1000 grafts in 1951 , with the aim to 
COMMERCIALLY IMPORTANT POTATO VARIETIES DURING 1945-1973 DEVELOPED BY LATVIA POTATO BREEDERS

\begin{tabular}{|c|c|c|c|c|}
\hline Variety & $\begin{array}{c}\text { Year of } \\
\text { realization }\end{array}$ & Pedigree & Breeders & $\begin{array}{l}\text { Included in the list of varieties } \\
\text { recommended for production in } \\
\text { territory of Latvia }\end{array}$ \\
\hline Priekulu Visagrie (Erna) & $1931-1940^{1}$ & Irish cobler / Jubel & Priekuḷi $^{2}$ : E. Knappe, E. Pētersons & $1953-2003$ \\
\hline Eksports (Zemgales brīnums) & $1931-1940$ & Primadonna / Pepo & Priekuḷi: E. Knape & 1956-1969 \\
\hline Zeltīte & 1931-1940 & Erstling / Eksports & Priekul,i: E.Knape etc. & 1958-1964 \\
\hline Laimdota & $1931-1940$ & Majestic / Export & Priekuḷi: E. Knappe, E. Pētersons, V. Gaujers & Since 1957 \\
\hline Agrie Dzeltenie & $1931-1940$ & Zīle (1457.8) / 1649.9 & Priekuḷi: E. Pētersons, V. Gaujers & Since 1962 \\
\hline Stendes Baltie & 1956 & Vāle / Hindenburg & Stende $^{3}:$ J. Strazds, A. Dance, A. Tumova & 1959 \\
\hline Carnikava & 1957 & Kungla / Oktjabrjonok & Carnikava $^{4}$ : A. Aṇikijevs & $1957-1965$ \\
\hline Izstādes & 1953 & V5018-2 / Agra & Priekul,i: V. Gaujers & 1964-1973 \\
\hline Vita & 1973 & 5018-2 / Kameraz & Priekuḷi: V. Gaujers, M. Oša, N. Ķesa & 1973 \\
\hline
\end{tabular}

${ }^{1}$ The year of realization was not stated; ${ }^{2}$ Priekuli Plant Breeding Station; ${ }^{3}$ Stende Plant Breeding Station; ${ }^{4}$ Carnikava Potato Breeding and Experimental Station

obtain samples resistant to potato wart from variety 'Vāle', which had been sensitive to wart. These efforts did not bring success.

Besides the work at Priekuli, potato breeding was conducted in several other institutions in Latvia during the 1940s: Lejaskurzeme Experimental Station (1946-1953), Stende Plant Breeding and Experimental Station (1948-1953) and Soviet Union Alcohol Production Research Institute Latvian Zonal Potato Breeding and Experimental Station at Carnikava (1948-1963) (Holms, 1992).

Hybridisation between potato species and varieties as well as vegetative hybridisation was conducted in Stende by breeders Jānis Strazds and Anna Dance. The breeding material of the remarkable potato breeder P. Knappe was evaluated and also propagated at that timel. The period of time was too short to obtain valuable results. The greatest success was the submission of potato variety 'Stendes Baltie' for State evaluation trials (Table 2).

The breeding work in Carnikava was conducted by agronomist Aleksandrs Anikijevs, who used clonal selection from potato varieties, development of clones from buds, and generative and vegetative hybridisation. The hybridisation between varieties was the most successful method. A. Anikijevs developed the early maturity variety 'Carnikava', which was accepted for

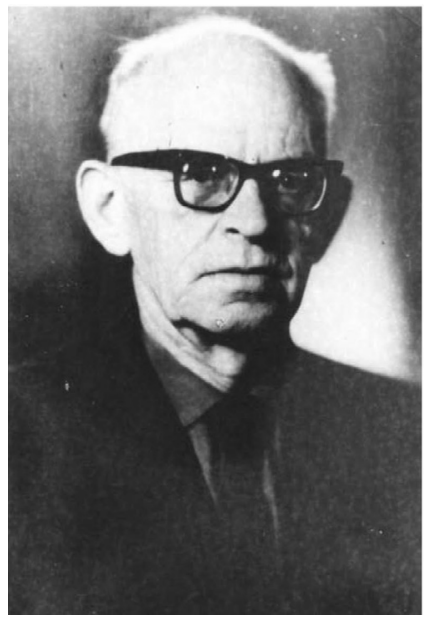

Potato breeder Emīls Pētersons, during and after the Second World War. 1950s production in Latvia (Table 2), and in production was used for producing two yields in one season in the Ukraine USR in 1970s. Later, A. Aṇikijevs moved to Priekuḷi and continued potato breeding to develop varieties suitable for processing.

At Lejaskurzeme, agronomist Vilis Gaujers started potato breeding, using all known methods of other breeders at that time in SU. The aim of breeding was to develop varieties with excellent culinary traits and high starch content.

\section{EXTENSION OF WORK IN PRIEKULI}

V. Gaujers moved to Priekuḷi Plant Breeding and Experimental Station to lead potato breeding work in 1953. The evaluation of existing breeding material was continued and resulted in accepted varieties. The potato breeding programme was expanded, and 40 000-100 000 seedlings were produced during the first generation of the breeding programme. Phytophatologists and agrochemists were involved in the breeding work. The evaluation of breeding material resistance to late blight using artificial inoculation was started, and composition of races in the late blight population was determined by Mirdza Bērziņa and Marija Oša (Holms, 1992). The research on potato virus diseases was carried out by Vija Ūdre, but Genoveva Dortāne-Lakše tested resistance to bacterial dis-

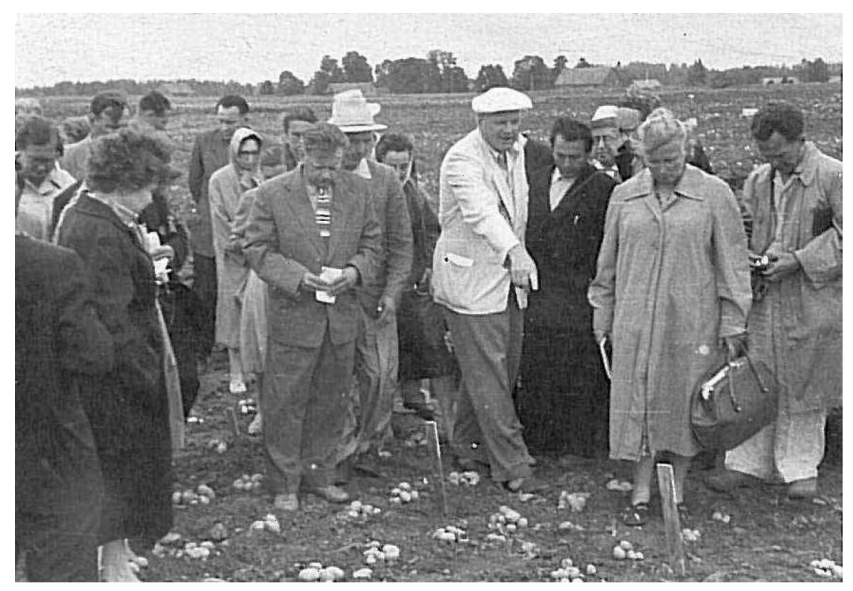

Potato breeder V. Gaujers (in the centre) with visitors in potato breeding field, $1960 \mathrm{~s}$ 


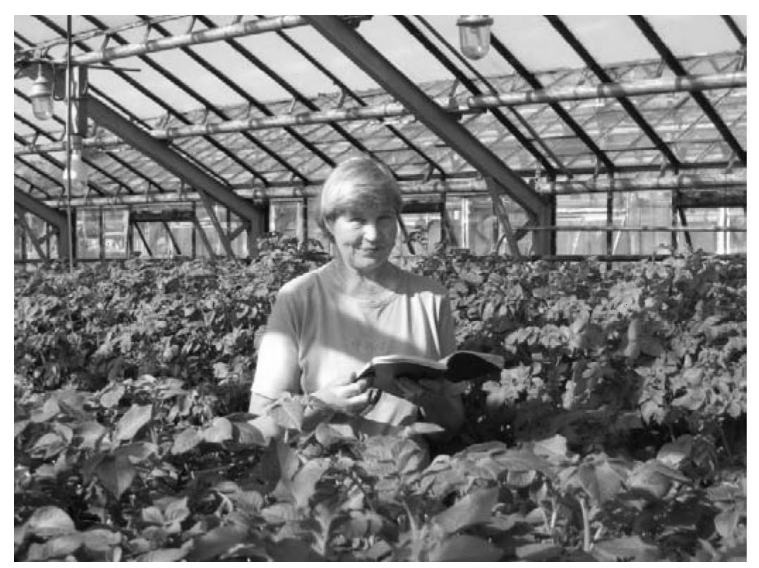

Potato breeder Marija Oša assessing potato seedlings, 2003

eases of potato. Important studies on potato dry rot (Fusarium sp.) were carried out by Gunta Bebre (Bebre, 2003).

Mostly hybridisation between varieties and potato species was used in obtaining genotypic diversity. Several developed varieties were introduced in production and became popular in the second part of the 20th century (Tables 2, 3). Potato varieties 'Agrie Dzeltenie', 'Vita', 'Madara', 'Skaidra' and others were grown for table or market consumption. A part of potato production was used for feed at that time. The high yielding variety 'Laimdota' and variety 'Astra' were offered for this kind of production. For potato starch production, medium late varieties 'Brasla', 'Zīle', 'Sarmina' and others were developed.

Technician Alberts Saulīe, working in Priekuḷi Station, attempted to involve methods of mutagenesis in breeding potato since 1963 . He used physical mutagens ( $\gamma$ rays and fast neutrons) and several chemical mutagens in different doses and concentrations for treatment of true seed and tuber. Later, when A. Saulītis left work at Priekuli, he developed several potato varieties from treated breeding material. The early variety 'Mutagenagrie' became popular in Latvia (Table 3).

Potato breeder A. Anikijevs used methods of mutagenesis in breeding work as well, and later some efforts were made by Jānis Katajs-Paeglis (Holms, 1992; Bebre, 2003).

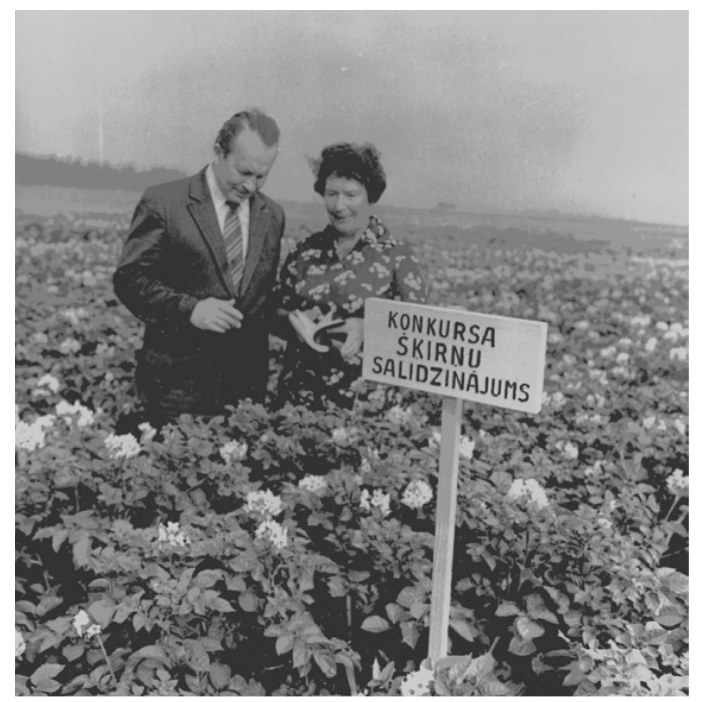

Potato breeders Jānis Katajs-Paeglis and Nanija K,esa in potato breeding field, 1980 s
The newest methods were involved not only in potato breeding, but also in seed production. The laboratory of tissue culture was established in 1978 with an aim to acquire methods for elimination of virus diseases in potato and to establish production of healthy initial potato seed material. The acquisition and adaptation of a methodology suited to local conditions took ten years. With the support of V. Gaujers and advice of Uldis Miglavs on potato viruses, several researchers Mirdza Zarina, Māra Robežniece, Aija Gābere — were involved in the studies and development of the technology. As a result, the potato seed production system where healthy virus free in vitro plants were used as initial material, had been developed in Priekuli and in the territory of Latvia since 1985.

The time of generation changes occurred in the 1970s. Breeding material of A. Anikijevs was taken over by Nanija Kesa in 1977. Besides breeding, she worked on improvement of seed production. Marija Oša joined potato breeding in 1979; she continued work with potato breeding material developed by V. Gaujers. Later Gunta Bebre replaced N. Kesa in 1985.

The researchers and breeders participated in scientific conferences within the SU, exchanging experience with researchers of other soviet republics. Cooperation was established with other institutions dealing with potato breeding and research: Jõgeva Plant Breeding and Experimental Station (Estonia), Voke Department of Potato Breeding (Lithuania), Potato Research Institute in Belorussia, Potato Research institute in Ukraine, Potato Production Institute in Moscow (Russia) and others. Germplasm for breeding purposes was received from Vavilov Plant Production Institute in Leningrad (Russia) collections.

The processing of potato chips and crisps began to develop in Latvia in the 1990s; the production of potato starch was enlarged in Latvia. The assessment of specific traits for processing was included in the potato breeding programme. Resistance to nematode Globodera rostochnensis became one of the important traits for newly developed varieties. The newest potato varieties (developed in 1990s) were resistant to $G l$. rostochinensis pathotype Ro1: 'Brasla', 'Lenora', 'Magdalena', 'Monta', 'Imanta' and others (Table 3).

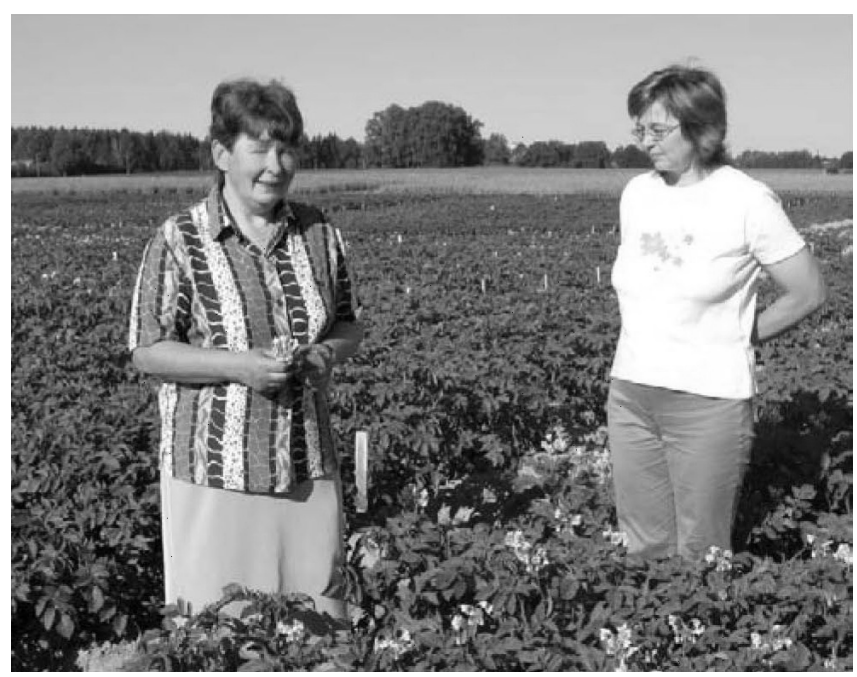

Potato breeders Gunta Bebre and Ilze Skrabule, 2003 
CHARACTERIZATION OF POTATO VARIETIES DEVELOPED AND REGISTERED FROM 1985 TO 2012

\begin{tabular}{|c|c|c|c|c|}
\hline Variety & Pedigree & Breeders & Year of registration & Specific traits \\
\hline \multicolumn{5}{|c|}{ Early maturity } \\
\hline Madara & Amaryl / plantlet10792.2 & Priekul,i ${ }^{1}$ : V. Gaujers, M. Oša etc. & 1992 & \\
\hline Mutagenagrie & & A. Saulītis & 1993 & \\
\hline Spīdola & & A. Saulītis & & $\mathrm{N}^{2}$ \\
\hline Monta & 16934.1/Ausonia & Priekuḷi: M. Oša & 2003 & $\mathrm{~N}$ \\
\hline Agrie Baltie & & A. Saulītis & 2004 & $\mathrm{~N}$ \\
\hline \multicolumn{5}{|c|}{ Medium early maturity } \\
\hline Skaidra & Frila / Kristal & Priekuḷi: M. Oša, V. Gaujers etc. & 1988 & $\mathrm{~N}$ \\
\hline Lenora & $15703 \mathrm{ks} / 15335.9$ & Priekul̦i: V. Gaujers, M. Oša etc. & 2002 & $\mathrm{~N}$ \\
\hline Prelma & Ibis / Rosara & Priekuḷi: M. Oša & 2010 & $\mathrm{~N}$ \\
\hline \multicolumn{5}{|c|}{ Medium late maturity } \\
\hline Sarminga & Gauja / Soidinskij Rannij & Priekuḷi: V. Gaujers, M. Oša etc. & 1986 & $\mathrm{~S}^{3}$ \\
\hline Brasla & 15709KS / 15335.9 & Priekuḷi: M. Oša & 1995 & $\mathrm{~N}, \mathrm{~S}$ \\
\hline Bete & 13108.2 / Wilja & Priekuḷi: M. Oša, V. Gaujers & 1999 & \\
\hline Magdalena (Magda) & $82-28.9 / 15876.41$ & Priekuḷi: G. Bebre & 2002 & $\mathrm{~N}$ \\
\hline Sigunda (Unda) & $80-348.16 / 59-99.24$ & Priekulii: G. Bebre, N. Ķesa & 2002 & $\mathrm{LB}^{4}$ \\
\hline Sniegoga & & A. Saulītis & 2005 & \\
\hline Talmuts & & A. Saulītis & 2005 & \\
\hline Daugava & & A. Saulītis & 2005 & \\
\hline Imanta & Picaso/Zarevo & Priekuḷi: G. Bebre & 2008 & $\mathrm{~N}, \mathrm{LB}, \mathrm{S}$ \\
\hline Mandaga & Picaso/Zarevo & Priekuḷi: G. Bebre & 2010 & $\mathrm{~N}$ \\
\hline Gundega & 82-12.32 / Zarevo // Ausonia & Priekuḷi: G. Bebre & 2011 & $\mathrm{~N}, \mathrm{LB}$ \\
\hline
\end{tabular}

${ }^{1}$ Priekul,i Plant Breeding Station or State Priekul,i Plant Breeding Institute; ${ }^{2}$ Resistant to nematode Globodera Rostochinensis Ro1; ${ }^{3}$ High starch content;

${ }^{4}$ High resistance to late blight Phytophtora infestans

\section{NEW CHALENGES IN POTATO BREEDING}

After restoring the independence of the Republic of Latvia in 1991, the opportunity to attend scientific conferences in Europe became possible. The potato breeders participated in the European Association for Potato Research. The newest trends in potato research and breeding were introduced. More attention to quality traits was paid, investigation of content of protein, vitamins, glycoalkaloids and other relevant to human health substances in potato breeding material were introduced (Skrabule et al., 2010; Murniece et al., 2011). Ilze Skrabule joined potato breeding in 1990s and has led the potato breeding programme since 2009.

In 2006, the name of Priekuli Plant Breeding and Experiment Station was changed to State Priekuli Plant Breeding Institute. It is the only place in Latvia where potato breeding as well as initial virus free potato seed material production is carried out.

The trends of sustainable agriculture using lower doses of pesticides have been significant for maintenance of the environment for future. Organic farming is a developing sector of agriculture not only in Europe, but in Latvia as well. The demand for varieties suitable for organic and low input agriculture has appeared in recent years. The evaluation of breeding material in organic growing conditions has been conducted and methods for evaluation of specific traits have been developed (Skrabule, 2010). Molecular markers have been used for detection of genes providing resistance to diseases and pests in

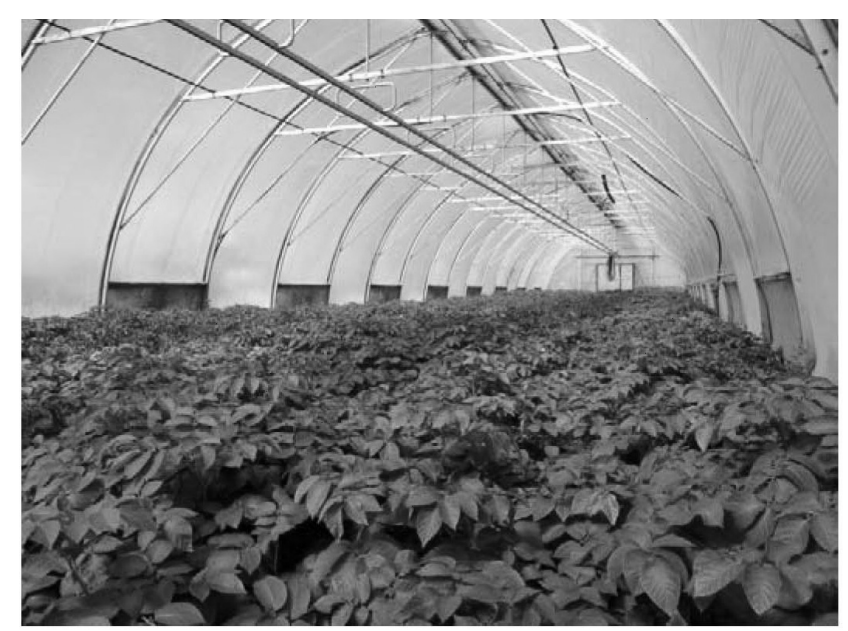

Virus-free initial potato seed material propagation in greenhouse, 2012

potato breeding material (Skrabule et al., 2011; Mežaka et al., 2012). The acquiring of near infrared technologies for assessment of potato quality traits has started. The research has been conducted in cooperation with geneticists (I. Mežaka), phytopathologists (G. Üsele, N. Zoteeva), seed producers (I. Dimante), food technologists, chemists, pharmacists and other specialists not only from Priekuḷi Institute, but also from other institutions.

The potato producers in Latvia completely provide the population of the country with potatoes. The potato production area 


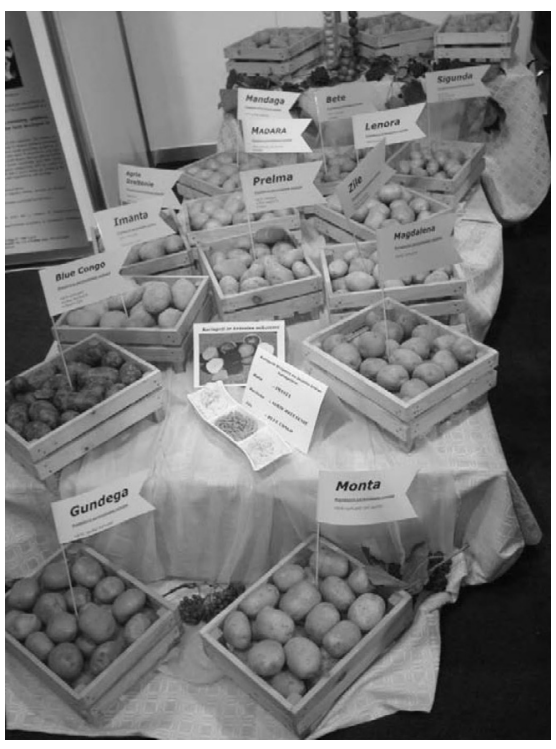

The stand of potato varieties, developed in Priekuḷi Plant Breeding Institute, International Exibition RigaFood, 2011

in 2011 was 29.6 thousand ha, the total production was 484 thousand tonnes (Anonymous, 2012). The aim of potato breeding still is to develop varieties suitable to local growing conditions and farming systems and according to consumer requirements. More than 60 potato varieties have been created in Latvia, some of them were and still are demanded in agricultural production. The breeding work is continuing to create potato varieties with resistance to several pathogens and excellent quality traits.

\section{REFERENCES}

Anonymoys (2011). Latvijas lauksaimniecība 2011 [Agriculture in Latvia 2011]. LRZM, retrieved February 20, 2013, from

http://www.zm.gov.lv/doc_upl/LS_2012.pdf (in Latvian).

Bebre, G. (2003). Kartupeḷu selekcijas līkloči [The road of potatoto breeding]. In: Priekuḷu selekcijas stacija celā uz simtagadi [Priekuḷi Plant Breeding Station on the Way to Centennial] (25.-31. 1pp.). Valmiera: Lapa (in Latvian).

Bebre, G. (2003). Kartupeḷ škirnes ‘Unda' izveide un raksturojums [The development and characteristics of potato variety 'Unda']. Agronomijas Vēstis, 5, 70-76.

Bebre, G. (2004). Kartupel̦u šķirnes 'Magdalena' izveide un raksturojums [The development and characteristics of potato variety 'Magdalena']. Agronomijas Vēstis, 6, 148-154.

Bradshaw, J. E., Mackay, G. R. (1994). Breeding strategies for clonally propagated potatoes. In: Bradshaw, J. E., Mackay, G. R. (eds.). Potato Genetics (pp. 467-498). CAB International.

Gaujers V. (1969). Kartupeḷ [Potatoe]. Rīga: Liesma. 210 lpp. [in Latvian].

Gaujers, V. (1983). Kartupelu škirnes un selekcija [Potato Varieties and Breeding]. Rīga: Zinātne. 58 lpp. [in Latvian].
Gābere, A. (2003). Kartupelu atveselošanas laboratorija [The potato recovering laboratory]. In: Priekuḷ selekcijas stacija ceḷā uz simtagadi [Priekuḷi Plant Breeding Station on the Way to Centennial] (31.-32. lpp.). Valmiera: Lapa (in Latvian).

Holms, I. (1992). Kartupeḷu selekcija [Potato breeding]. In: Laukaugu selekcija Latvijā [Crop breeding in Latvia] (97. -112. lpp.). Rīga: Avots (in Latvian).

Mežaka, I., Vilcāne, D., Ūsele, G., Skrabule, I., Rostoks, N. (2012). First results of marker assisted selection of Latvian potato breeding material for resistance to potato cyst nematode Globodera rostochinensis. In: Materials of the International Scientific Conference ,, Diversity in Plant Breeding and Agriculture: Strategies for Healthy Lifestyle”, Talsi, Latvia, May 30-June 1, 2012 (p. 40). Talsi: State Stende Cereals Breeding Institute.

Miglavs, U., Katajs-Paeglis, J., Bebre, G., Oša, M. (1991). Kartupeḷu selekcija [Potato breeding]. In: Augsne, selekcija, augkopība [Soil, Plant Breeding, Crop Production] (pp. 45-47). Rīga: Zvaigzne.

Murniece, I., Karklina, D., Galoburda, R., Santare, D., Skrabule, I., Costa, H. S. (2011). Nutritional composition of freshly harvested and stored Latvian potato (Solanum tuberosum) varieties depending on traditional cooking methods. In: J. Food Composit. Anal., 24, 699-710.

Roze, K. (1954). 40 gadu darba pieredze kartupeḷu selekcijā [The Experience of 40 Years in Potato Breeding]. Rìga: LPSR ZA izdevniecība. 59 lpp.

Roze, K. (1961). Jaunas kartupeḷu škirnes [New Potato Varieties]. Rīga: LPSR ZA izdevniecība. 57 lpp.

Roze, K., Knape, P. (1953). Kartupeḷu starpsugu hibridizācijas rezultāti [The results of potato species hybridisation]. In: Augḷkopība un dārzeņkopība (rakstu krājums) [Horticulture (compedium of articles)] (pp. 177-208). Rīga: LPSR ZA izdevniecība.

Salaman, R. N. (1947). The History and Social Influence of the Potato. Cambridge University Press. 685 pp.

Skrabule, I. (2010). Evaluation of potato breeding clones in organic and conventional growing conditions. In: EUCARPIA 2 nd conference of the „Organic and low-input agriculture" section, Paris (pp. 102-105). Paris.

Skrabule, I., Grauda, D., Mikelsone, A., Vasariete, A. (2010). Adaptation of glycoalkaloids detection method for evaluation of Latvian potato genetic resources. Agron. Res., 8, Special Issue 3, 705-710.

Skrabule, I., Zoteyeva, N., Mezaka, I., Vilcane, D., Usele, G. (2011). The adaptation of MAS for late blight resistance evaluation of potato breeding material. In: Proceedings of the Thirteenth EuroBlight Workshop, St. Petersburg, Russia (pp. 179-186). St. Petersburg.

Strods, H. (1992). Latvijas lauksaimniecības vēsture [The History of Latvian Agriculture]. Rīga: Zvaigzne. 287 lpp. (in Latvian).

Zute, S., Belicka, I., Kalmans, Z. (2012). State Stende Cereal Breeding Institute: From the origins to the present. Proc. Latvian Acad. Sci., Section B, 66 (1/2), 59-70.

Букасов С. М. (1973). Систематика и география видов картофеля [Systematics and geography of potato types]. In: Генетика картофеля [Роtato Genetics]. (c. 14-34). Москва: Наука (in Russian).

Саулите А. (1987). Некоторые итоги применения экспериментального мутагенеза в селекции картофеля [Some results from trials of experimental mutagenesis in potato breeding]. В кн.: Генетика и селекция в Латвийской ССР [Genetics and Plant Breeding in Latvian SSR] (c. 68-71). Рашаль, И. Д. (ред.) Рига: Звайгзне (in Russian).

\section{KARTUPELU ŠKIRNU VEIDOŠANA LATVIJĀ}

Pirmās kartupeḷu šķirnes, kas nonāca Latvijas teritorijā, bija empīriski veiktas klonu izlases no genotipiski daudzveidīga materiāla, kas Eiropā bija ieceḷojis no Dienvidamerikas. Veidojoties lauksaimnieciskajai ražošanai, radās nepieciešamība audzēt tādas šḳirnes, kas būtu augstražīgas vietējos audzēšanas apstākḷos. Tāpēc tika iekārtoti ievesto kartupeḷu šḳirṇu salīdzināšanas izmēǵinājumi. Zinātniski pamatotu kartupeḷu selekcijas darbu Latvijas teritorijā aizsāka P. Knappe. Priekuḷu selekcijas stacijā kartupeḷu šķirṇu veidošana sākās 1931. gadā, un šis darbs tiek joprojām turpināts. Laika gaitā izmantojot dažādas selekcijas metodes, Priekuḷos strādājuši selekcionāri E. Knappe, V. Gaujers, G. Bebre un citi. Kartupeḷu selekcijas darbs dažādos periodos veikts arī Stendē, Carnikavā un Lejaskurzemē. Kartupeḷu škirņu augstvērtīga sēklas materiāla ieguvei Priekulıs izstrādāta kartupeḷu atveseḷošanas un vesela izlases sēklas materiāla ieguves metodika. Kopumā kartupeḷu selekcionāri Latvijā izaudzējuši vairāk nekā 60 kartupeḷu šḳirnes, kuras ieguvušas lielāku vai mazāku ievērību zemnieku vidū. 